15. De Vuyst, L., Vanderveken, F., Van de ven, S. and Degeest, B., Production by and isolation of exopolysaccharides from Streptococcus thermophilus grown in milk medium and evidence for their growth associated biosynthesis. J. Appl. Microbiol., 1998, 8, 1059-1068.

16. Verhoef, R., Waard, P. D., Schols, H. A., Siika-aho, M. and Voragen, A. G. J., Methylobacterium sp. isolated from a Finnish paper machine produces highly pyruvate galactan exopolysaccharide. Carbohydr. Res., 2003, 338, 1851-1859.

17. Berg, G., Zachow, C., Lottmann, J., Gotz, M., Costa, R. and Smalla, K., Impact of plant species and site on rhizosphereassociated fungi antagonistic to Verticillium dahlia Kleb. Appl. Environ. Microbiol., 2009, 71, 4203-4213.

18. Kumari, P., Khanna, V. and Kumar, P., Multifaceted rhizobacteria mediated growth augmentation in chickpea. Agric. Res., 2017; doi:10.1007/s40003-017-0275-5.

19. Altomare, C., Norvell, W. A., Bjorkma, T. and Harman, G. E., Solubilization of phosphates and micronutrients by the plantgrowth-promoting and biocontrol fungus Trichoderma harzianum. Appl. Environ. Microbiol., 1999, 65, 2926-2933.

20. Suseelendra, D., Parveen, K. G., Uzma, S., Sravani, P., Mir, H. A. S. K., Leo, D. A. E. and Gopal, R., Potential microbial candiadate strains for management of nutrient requirements of crops. Afr. J. Microbiol. Res., 2012, 6, 3924-3931.

21. Spaepen, S., Vanderleyden, J. and Remans, R., Indole-3-acetic acid in microbial and microorganism-plant signaling. FEMS Microbiol. Rev., 2007, 31, 425-448.

22. Patten, C. L. and Glick, B. R., Role of Pseudomonas putida indole acetic acid in development of the host plant root system. Appl. Environ. Microbiol., 2002, 68, 3795-3801.

23. Bottini, R., Cassán, F. and Piccoli, P., Gibberellin production by bacteria and its involvement in plant growth promotion and yield increase. Appl. Microbiol. Biotechnol., 2004, 65, 497-503.

24. Probanza, A., García, J. A. L., Palomino, M. R., Ramos, B. and Manero, F. J. G., Pinus pinea L. seedling growth and bacterial rhizosphere structure after inoculation with PGPR Bacillus (B. licheniformis CECT 5106 and B. pumilus CECT 5105). Appl. Soil. Ecol. 2002, 20, 75-84.

25. Ali, S. Z., Sadhya, V. and Rao, L. V., Isolation and characterization of drought-tolerant ACC deaminase and exopolysaccharide-producing fluorescent Pseudomonas sp. Ann. Microbiol., 2013, 64, 492-502.

26. Hontzeas, N., Richardson, A. O., Belimov, A., Safronova, V., Abu-Omar, M. M. and Glick, B. R., Evidence for horizontal transfer of 1-aminocyclopropane-1-carboxylate deaminase genes. Appl. Environ. Microbiol., 2005, 71, 7556-7558.

27. Oldroyd, G. E. and Downie, J. A., Coordinating nodule morphogenesis with rhizobial infection in legumes. Annu. Rev. Plant. Biol., 2008, 59, 519-546.

28. Russelle, M. P., Biological dinitrogen fixation in agriculture. In Nitrogen in Agricultural Systems (eds Schepers, J. S. and Raun, W. R.), Agronomy Monograph, 2008, 2nd edn, pp. 281-359.

29. Andrade, G., Deleij, F. A. and Lynch, J. M., Plant mediated interactions between Pseudomonas fluorescens, Rhizobium leguminosarum and arbuscular mycorrhizae on pea. Lett. Appl. Microbiol., 1998, 26, 311-316.

30. Van peer, R., Niemann, G. J. and Schippers, B., Induced resistance and phytoalexin accumulation in biological control of Fusarium wilt of carnation of Pseudomonas sp. WCS417r. Phytopathology, 1991, 81, 726-730.

31. Hemissi, I., Mabrouk, Y., Abdi, N., Bouraoui, M., Saidi, M. and Sifi, B., Effects of some Rhizobium strains on chickpea growth and biological control of Rhizoctonia solani. Afr. J. Microbiol. Res., 2011, 5, 4080-4090.

32. Martínez-Viveros, O., Jorquera, M. A., Crowley, D. E., Gajardo, G. and Mora, M. L., Mechanisms and practical considerations involved in plant growth promotion by rhizobacteria. J. Soil Sci. Plant. Nutr., 2010, 10, 293-319.
33. Yasmin, F., Othman, R., Sijam, K. and Saad, M. S., Characterization of beneficial properties of plant growth promoting rhizobacteria isolated from sweet potato rhizosphere. Afr. J. Microbiol. Res., 2009, 3, 815-821.

34. Marco, J. S. D., Inglis, M. C. V. and Felix, C. R., Production of hydrolytic enzymes by Trichoderma isolates with antagonistic activity against Crinipellis pereniciosa, the causal agent of whitches broom of cocoa. Braz. J. Microbiol., 2003, 34, 33-38.

35. Azevedo, A. M. C., De Marco, J. L. and Felix, C. R., Characterization of an amylase produced by a Trichoderma harzianum isolate with antagonistic activity against Crinipellis perniciosa, the causal agent of witches' broom of cocoa. FEMS Microbiol. Lett., 2000, 188, 171-175.

36. Davey, M. E. and O'Toole, G. A., Microbial biofilms: from ecology to molecular genetics. Microbiol. Mol. Biol. Rev., 2000, 64, $847-867$.

37. Friedman, L. and Kolter, R., Genes involved in matrix formation in Pseudomonas aeruginosa PA14 biofilms. Mol. Microbiol., 2004, 51, 675-690.

38. Simons, M., van der Bij, A. J., Brand, I., de Weger, L. A., Wijffelman, C. A. and Lugtenberg, B. J. J., Gnotobiotic system for studying rhizosphere colonization by plant growth-promoting Pseudomonas bacteria. Mol. Plant-Microbe. Interact., 1996, 9, 600-607.

39. Paul, D. and Nair, S., Stress adaptations in a plant growth promoting rhizobacterium (PGPR) with increasing salinity in the coastal agricultural soils. J. Basic Microbiol., 2008, 48, 378-384.

40. Bogino, P. C., Oliva, M. M., Sorroche, G. F. and Giordano, W., The role of bacterial biofilms and surface components in plantbacterial associations. Int. J. Mol. Sci., 2013, 14, 15838-15859.

Received 18 July 2017; revised accepted 14 May 2020

doi: $10.18520 / \mathrm{cs} / \mathrm{v} 119 / \mathrm{i} 7 / 1197-1204$

\section{First fossil dragonfly from India}

\section{Manoshi Hazra ${ }^{1,2}$, Taposhi Hazra ${ }^{1}$, Subhankar Kumar Sarkar ${ }^{3}$, Subir Bera ${ }^{4}$ and Mahasin Ali Khan ${ }^{1, *}$}

${ }^{1}$ Palaeobotany-Palynology Laboratory, Department of Botany, Sidho-Kanho-Birsha University, Ranchi Road, Purulia 723 104, India ${ }^{2}$ Presidency University, 86/1, College Street, Calcutta University Road, Kolkata 700 073, India

${ }^{3}$ Entomology Laboratory, Department of Zoology,

University of Kalyani, Kalyani, Nadia 741235 , India

${ }^{4}$ Centre of Advanced Study, Department of Botany,

University of Calcutta, 35, B.C. Road, Kolkata 700 019, India

In the Indian wetland palaeoecosystem, no dragonfly has been reported from the Cenozoic sediments until now. Here, we report a well-preserved fossil dragonfly (Odonata: Anisoptera) recovered from the late Neogene sediments of the Chotanagpur plateau, Jharkhand, eastern India. It is characterized by

*For correspondence. (e-mail: khan.mahasinali@gmail.com) 
well-preserved head, thorax and a long cylindrical abdomen with terminalia and four wings with longitudinal veins, cross-veins and characteristic small pterostigma at the apex. These significant morphological attributes reveal a close resemblance of the fossil specimen with modern dragonflies of the family Libellulidae (order: Odonata, sub-order: Anisoptera). To the best of our knowledge, there is no reliable occurrence of dragonfly in the Indian fossil record. The core distribution of the dragonfly, suggests that it thrived under a tropical, warm, humid climate during the depositional period. The fossil specimen was found associated with prolific and diversified tropical angiospermic plant remains, vertebrates and invertebrates that provided a suitable palaeoniche for the dragonfly to survive. In addition, the fossil material and associated angiospermic flora indicate the terrestrial as well as freshwater lacustrine environment in Chotanagpur plateau during the depositional period.

Keywords: Chotanagpur plateau, fossil dragonfly, Neogene deposits, palaeoenvironment, tropical climate.

ODONATA are one of the ancient orders of insects that appeared during the Permian ${ }^{1}$. The odonates are widely distributed in all geographical realms, but their diversity is highest in the tropics with nearly about 6000 species being reported from all over the world ${ }^{1,2}$. They act as good bio-indicators of a healthy riverine system ${ }^{1,3}$. Dragonflies constitute about half of the living species of Odonata $^{2}$. Their aquatic larvae are among the predominant invertebrate predators in streams, rivers, springs, lakeshores, ponds and marshes ${ }^{4}$. They feed upon a wide range of insects that are normally captured in flight. Some dragonflies migrate to follow favourable seasonal conditions $^{5}$. Some are known as flyers, spending most of their active life in flying and some are perchers, spending more time at rest ${ }^{6}$. A number of Mesozoic and Cenozoic deposits worldwide bear dragonfly fossils ${ }^{7-9}$, but no fossil dragonfly has been previously reported from India. From this point of view, the present fossil evidence of dragonfly from late Neogene of Chotanagpur plateau, Jharkhand, India is significant.

Recently, during a palaeontological fieldwork, a wellpreserved dragonfly impression was collected from the river-cutting sections (Rajdanda Formation) along Mahuadanr Valley $\left(23.40^{\circ} \mathrm{N}, 84.11^{\circ} \mathrm{E}\right.$; altitude $353 \mathrm{~m}$ asl), Jharkhand (Figure $1 a$ ). The Rajdanda Formation represents late Neogene sedimentary deposits of fluvial origin $^{10,11}$. Earlier some workers have considered the age of the Rajdanda Formation to be Pliocene ${ }^{11,12}$, but till date there is no definitive evidence for this. The fossiliferous sedimentary section in the present study comprises sandstone and shale (Figure $1 \mathrm{~b}$ ). The shaly horizon also contained abundant fossil biota, including angiosperm leaves, fruit remains, flowers, wood, insect and fish remains. The fossil dragonfly specimen (Figure $2 a$ ) was carefully re- covered using chisel and shovel. After cleaning, the morphographic features of the specimen were thoroughly studied and photographed using a digital camera (Canon Power Shot A720IS). The line drawing of the specimen was done using Corel Draw ver. 19 (Figure 2 b). Terms used to describe the present fossil dragonfly specimen are in conformity with the standard terminologies for architectural description of fossil dragonflies ${ }^{13,14}$. The fossil specimen (SKBUH/PPL/JH/I2) is kept at the Herbarium and Museum, Department of Botany, Sidho-KanhoBirsha University, Purulia, India. A thorough morphological description of the fossil specimen is presented below.

Specimen well-preserved and almost complete; total body length $28-30 \mathrm{~mm}$, body width $7-8 \mathrm{~mm}$; wings four, two fore wings and two hind wings preserved, hyaline, membranous, wing nodes black, both wings with small pterostigma near their apex, five longitudinal veins, viz. costa, sub-costa, radius (R1 and R2), media and cubitus with characteristic cross-veins present on both fore and hind wings, inter radius 1 and 2 are also visible on the hind wing, fore wings preserved, length 17-23 mm, width 5-5.8 $\mathrm{mm}$, margin with a slight curvature, hind wings preserved, length 15-21 mm, width 6.9-12 mm, margin slightly bending to the hind margin distally; head $6 \mathrm{~mm}$, well-preserved; compound eyes not confluent; thorax well-preserved, present between head and abdomen, about $7.8 \mathrm{~mm}$ long and $6 \mathrm{~mm}$ wide, rather indiscernible; abdomen long, bulky, and cylindrical with three visible segments; terminalia present, very short; two hind legs preserved, femur and tibia visible on hind leg, femur $6 \mathrm{~mm}$ and tibia $9 \mathrm{~mm}$ in length respectively, no fore leg preserved in the fossil specimen.

The above-mentioned morphological features (viz. body size, shape of thorax, nodes, pterostigma, longitudinal veins and cross veins of wings, shape and length of the abdomen, shape of terminalia) of the specimen suggest its closest resemblance to those of the modern dragonfly members of the family Libellulidae. The present fossil specimen resembles the Recent Libellula depressa L., a common inhabitant of lakes and ponds. We need more samples and morphometric analyses to confirm their generic affinity. Libellulidae ranks among the most diverse and widespread groups of dragonflies with only few fossil records ${ }^{15,16}$, and is apparently the youngest anisopteran family of dragonflies. Libellulidae dragonflies are known as perchers as they spend more time at rest, basking in the sun, and take short flights for food or mate $^{6}$. The oldest fossil Libellulidae was reported from the Upper Cretaceous of Kazakhstan ${ }^{7}$. It is also recorded from early Middle Miocene of Heggbach in southern Germany ${ }^{15}$, and Miocene (Lower-Sarmatian) of the Tunjice Hills, Slovenia ${ }^{16}$.

The dragonfly prefers to live in tropical, warm, humid climate $^{17}$. In this context, the present fossil evidence suggests the existence of a tropical, warm and humid climatic 


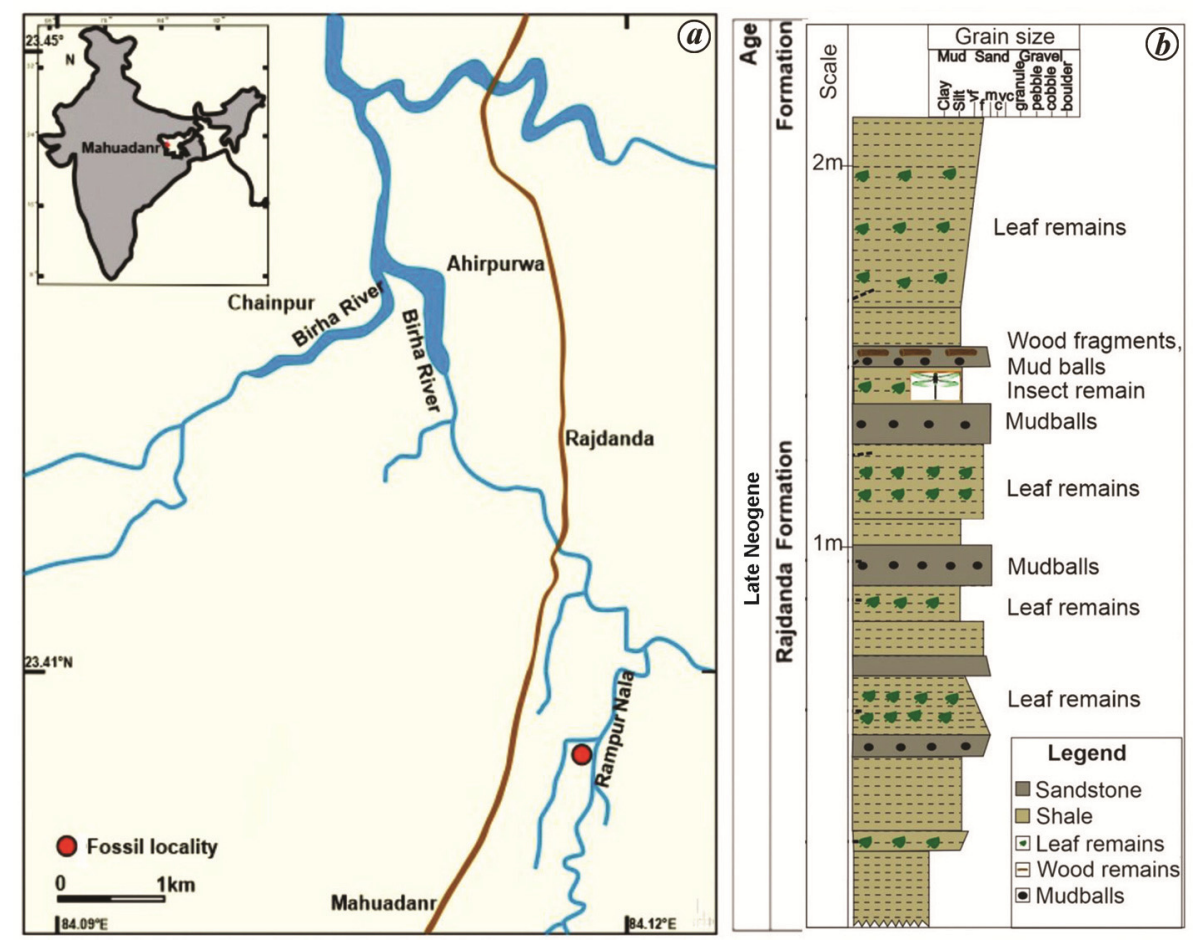

Figure 1. $\boldsymbol{a}$, Fossil locality map of the area near Mahuadanr, Latehar district, Jharkhand, India (modified from Toposheet No. F45A3 of the Survey of India). $\boldsymbol{b}$, Sedimentary section showing lithounits with a composite graphic $\log$ of $3 \mathrm{~m}$ of exposed sedimentary section using software SedLog 3.0.
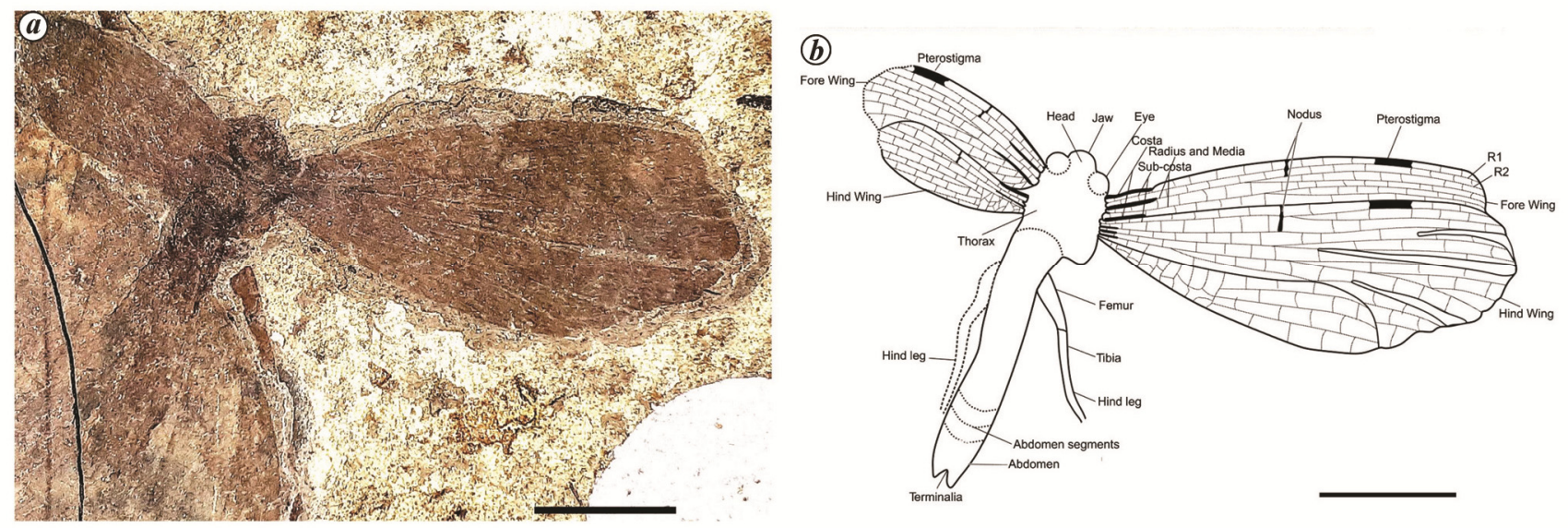

Figure 2. $\boldsymbol{a}$, Recovered fossil dragonfly specimen $(\mathrm{SKBUH} / \mathrm{PPL} / \mathrm{JH} / \mathrm{I} 2) . \boldsymbol{b}$, Line drawing of fossil specimen (scale bar $=1 \mathrm{~cm})$.

condition during the depositional period. Earlier palaeontological evidence also suggested that Chotanagpur plateau experienced a tropical climate ${ }^{10,18-20}$. Recently, the past climate of Chotanagpur plateau was estimated using CLAMP (Climate Leaf Analysis Multivariate Program) based on recovered fossil leaf architectural signatures ${ }^{11}$. CLAMP data also suggested a monsoonal, tropical, warm, humid climate in this region during the late Neogene.

The life cycle of the dragonfly begins in a pond. Dragonflies are known as 'guardians of the watershed' and 'wetland bio-indicators" ${ }^{21,22}$. They are carnivorous and feed on other insects like moths, flies, mosquitoes, bugs, midges, eye gnats, beetles, butterflies, damselflies and also on other dragonflies ${ }^{23}$. They perch on the rocks and sand near water bodies ${ }^{24}$. So, the fossil evidence of dragonfly in the sediments of Rajdanda Formation of Chotanagpur plateau suggests a freshwater lacustrine environment at the time of its deposition. The earlier record of fossil fishes and insects from the same sediments also suggests the same environment ${ }^{10,25}$. So, the earlier fossil evidence of diversified angiospermic plant 
remains, vertebrate and invertebrate remains suggests mixing of fauna and flora in fully shallow freshwater conditions. The presence of fossil flies, midges and butterflies in the fossil locality suggests that the dragonflies probably fed on these insects at that time. Thus, the late Neogene tropical forests of Jharkhand comprising abundant flora and fauna provided a suitable palaeoniche for the libellulid dragonfly to survive.

1. Emiliyamma, K. G., Systematic studies on Odonata (Insecta) of southern Western Ghats. Rec. Zool. Surv. India, 2014, 114, 57-87.

2. Dijkstra, K. D. B. et al., The classification and diversity of dragonflies and damselflies (Odonata). In (ed. Zhang, Z.-Q.), Animal Biodiversity: An Outline of Higher-level Classification and Survey of Taxonomic Richness (Addenda 2013). Zootaxa, 2013, 3703, 36-45.

3. Das, S. K. et al., Odonates of three selected tiger reserves of Madhya Pradesh, Central India. Check List, 2013, 9, 528-532.

4. Cannings, R. A., Introducing the dragonflies of British Columbia and the Yukon. Royal British Columbia Museum, Victoria, British Columbia, Canada, 2002, 1-97.

5. Anderson, R. C., Do dragonflies migrate across the western Indian Ocean? J. Trop. Ecol., 2009, 25, 347-358.

6. Corbet, P. S., Dragonflies: Behavior and Ecology of Odonata, Cornell University Press, Ithaca, New York, USA, 1999.

7. Fleck, G., Nel, A. and Martınez-Delclos, X., The oldest record of libellulid dragonflies from the Upper Cretaceous of Kazakhstan (Insecta: Odonata, Anisoptera). Cretac. Res., 1999, 20, 655-658.

8. Archibald, S. B. and Cannings, R. A., Fossil dragonflies (Odonata: Anisoptera) from the early Eocene Okanagan Highlands, western North America. Can. Entomol., 2019, 151, 783-816.

9. Zheng, D., Wang, H., Nel, A., Dou, L., Dai, Z., Wang, B. and Zhang, H., A new damsel-dragonfly (Odonata: Anisozygoptera: Campterophlebiidae) from the earliest Jurassic of the Junggar Basin, northwestern China. Alcheringa: Australasian J. Palaeontol., 2019, 43, 563-567.

10. Puri, S. N. and Mishra, V. P., On the find of Upper Tertiary plant, fish and bird fossils near Rajdanda, Palamau district, Bihar. Rec. Geol. Surv. India, 1982, 112, 55-58.

11. Hazra, T. et al., Latest Neogene monsoon of the Chotanagpur Plateau, eastern India, as revealed by fossil leaf architectural signatures. Palaeogeogr., Palaeoclimatol., Palaeoecol., 2020, https://doi.org/10.1016/j.palaeo.2020.109641.

12. Srivastava, G. P. and Bande, M. B., Fossil woods of Terminalia and Lagerstroemia from the late Cenozoic beds of Mahuadanr, Palamu District, Bihar. Palaeobotanist, 1992, 39, 333-337.

13. Riek, E. F., A new collection of insects from the Upper Triassic of South Africa. Ann. Natal Mus., 1976, 22, 791-820.
14. Riek, E. F. and Kukalova-Peck, J., A new interpretation of dragonfly wing venation based upon Early Carboniferous fossils from Argentina (Insecta: Odonatoidea) and basic character states in pterygote wings. Can. J. Zool., 1984, 62, 1150-1166.

15. Bechly, G. and Sach, V. J., An interesting new fossil dragonfly (Anisoptera: Libellulidae 'Brachydiplacini') from the Miocene of Germany, with discussion on the phylogeny of Tretathemistinae and a fossil list for the locality Heggbach. Stut. Beitr. Nat. Kd. Ser. B., 2002, 325, 1-11.

16. Zessin, W., Zalohar, ' J. and Hitij, T., A new fossil dragonfly (Insecta, Odonata, Libellulidae) of the Miocene (Lower Sarmatian) of the Tunjice Hills, Slovenia. Bull. Entomol. Assoc. Mecklenburg, 2008, 11, 86-96.

17. Tiple, A. D. and Koparde, P., Odonata of Maharashtra, India with notes on species distribution. J. Insect Sci., 2015, 15, 47.

18. Singh, S. K. and Prasad, M., Late Tertiary leaf flora of Mahuadanr valley, Jharkhand. J. Palaeontol. Soc. India, 2007, 52, 175-194.

19. Singh, S. K. and Prasad, M., Fossil leaf-impressions from the Late Tertiary sediments of Mahuadanr valley, Latehar District, Jharkhand, India. Palaeobotanist, 2008, 57, 479-495.

20. Singh, S. K. and Prasad, M., Addition to the Upper Tertiary flora of Mahuadanr valley, district Latehar, Jharkhand, India. Proc. Natl. Acad. Sci. India, Sect. B, 2009, 79, 402-409.

21. Silva, D. P., De Marco, P. and Resende, D. C., Adult odonate abundance and community assemblage measures as indicators of stream ecological integrity: a case study. Ecol. Indic., 2010, 10, 744-752.

22. Clausnitzer, V. and Jödicke, R., Guardians of the watershed. Global status of dragonflies: critical species, threat and conservation. Int. J. Odonatol., 2004, 7, 239-253.

23. Burange, P. S., Wargantiwar, R. K. and Kaur, N., Dragonfly: Environment Indicator and its conservation, Popular Kheti, 2014.

24. Subramanian, K. A. and Babu, R., Checklist of Odonata (Insecta) of India. 2017, Version 3.0; www.zsi.gov.in

25. Shukla, M., Kumar, P., Srivastava, G. P. and Kumar, M., Record of resin embedded insects and related organic remains from Mahuadanr Valley, Palamu, India. Curr. Sci., 2000, 78, 385-386.

ACKNOWLEDGEMENTS. M.H., T.H. and M.A.K. thank the Department of Botany, Sidho-Kanho-Birsha University, Purulia for providing the necessary facilities to carry out this work. S.K.S. thanks the Department of Zoology, University of Kalyani, Nadia for providing the necessary facilities for this study. S.B. thanks the Centre of Advanced Study, Department of Botany, University of Calcutta, Kolkata for providing the necessary facilities for this study.

Received 19 June 2020; revised accepted 29 July 2020

doi: $10.18520 / \mathrm{cs} / \mathrm{v} 119 / \mathrm{i} 7 / 1204-1207$ 